\title{
THE IMPACT OF UNEMPLOYMENT, MINIMUM WAGE, AND REAL GROSS REGIONAL DOMESTIC PRODUCT ON POVERTY REDUCTION IN PROVINCES OF INDONESIA
}

\section{Dur Feriyanto ${ }^{1+}$ \\ Dityawarman El Aiyubbi $^{2}$ \\ Achmad Nurdany}

\author{
${ }^{1,2}$ Department of Economics, Faculty of Business and Economics, Universitas \\ Islam Indonesia, Yogyakarta, Indonesia. \\ ${ }^{2}$ Email:nur.feriyanto@uiz.ac.id Tel: +62811282632 \\ 'Email:el.aiyubbi@uiz.ac.id Tel:+6281285592967 \\ ${ }^{3}$ Department of Sharia Economics, Universitas Islam Negeri Sunan \\ Kalijaga, Yogyakarta, Indonesia. \\ sEmail: achmad.nurdany@uin-suka.ac.id Tel: +6285641442494
}
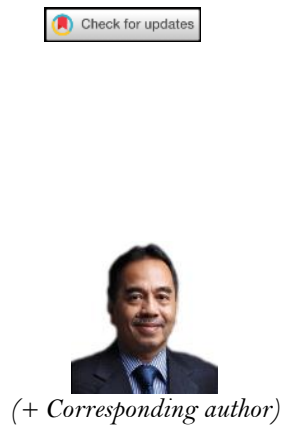

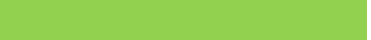

\section{Article History}

Received: 28 July 2020

Revised: 2 September 2020

Accepted: 5 October 2020

Published: 13 October 2020

\section{Keywords}

Unemployment

Wage

Real GRDP

Poverty

Indonesia

Government policy.

JEL Classification: E60; I32; J31; J64.
$A B S T R A C T$

Poverty often impedes economic development in numerous countries, Indonesia included. Poverty, as a result of the failure of economic development, must continue to be suppressed and a solution sought, so that poverty no longer causes adverse effects for the country. The purpose of this study is to examine the impact of unemployment, minimum wage, and real gross regional domestic product (GRDP) on poverty reduction in the provinces of Indonesia. Using periodic data from the Central Bureau of Statistics (Badan Pusat Statistik-BPS) over the period 2010-2019, the fixed effect model of the panel data analysis is estimated. The result showed that unemployment and wage had a significant positive effect on poverty in provinces of Indonesia. Meanwhile, the real GRDP had a significant negative effect on poverty in Indonesia. Thus, government policy must focus on reducing unemployment, maintaining price stability to preserve wage levels and purchasing power, and increasing the real GRDP to reduce poverty in Indonesia.

Contribution/Originality: This study contributes to the existing literature in the field of human resource economics, particularly on the issue of poverty reduction. This study is one of the few studies that uses panel data and estimation using the fixed effect model on provinces in a country experiencing issues relating to poverty.

\section{INTRODUCTION}

Poverty has become one of the most talked about issues in socio-economics. It must be faced by all governments in the world, including Indonesia. A large number of poor people in a country will result in a heavy macroeconomic burden. It reduces the quality of life among the population due to the limited ability of poor people to fulfill their basic daily needs. Therefore, almost all governments in the world endeavor to minimize the number of poor people in order to realize a better quality life for their people. Support from the World Bank has been given to all countries since 1990 by aiming to reduce extreme poverty across the globe (Konkel, 2014).

Indonesia has 33 provinces with varying numbers of poor people in each province. Figure 1 shows the average number of poor people per year over the period 2010-2019. According to Figure 1, there are three provinces in Indonesia that have the highest poor population: East Java has 4,797,212 poor people, Central Java has 4,610,475 poor people, and West Java has 4,226,775 poor people. The three provinces with the lowest number of poor people 
per year are:Bangka Belitung Islands with 71,027 poor people, North Maluku with 84,641 poor people, and the Riau Islands with 126,620 poor people. The difference in the number of poor people in each province indicates the extent of the problem and how much needs to be done to reduce the number of people in poverty.

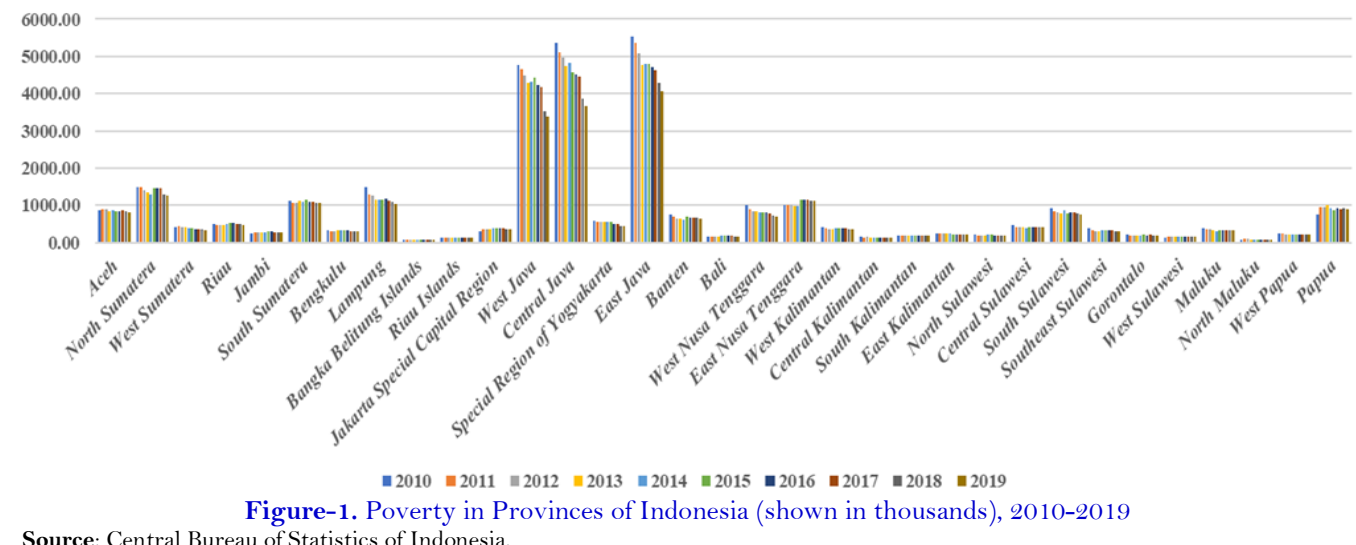

The highest number of unemployed people in Indonesia is in Java, the most populous island. The largest average number of unemployed per year over the period 2010-2019 is in the province of West Java with 1,859,909 unemployed, followed by Central Java with 936,983 unemployed, and East Java with 869,135 unemployed. Whereas, the lowest average number of unemployment is in the province of West Sulawesi with 16,612 unemployed, the province of Gorontalo with 22,615 unemployed and the province of North Maluku with 24,994 unemployed.

Unemployment is a hinderance to economic development in all provinces because the unemployed do not contribute to the economy, although they still need access to food, housing, healthcare, etc.. Unemployment is related to the efforts of local goverments to reduce the number of people out of work in their respective areas (see Figure 2). Research by Akinmulegun (2014) in Nigeria mentioned that unemployment is a major cause of poverty in the country. The study recommended that the government carry out a structural transformation in macroeconomic policies for employment.

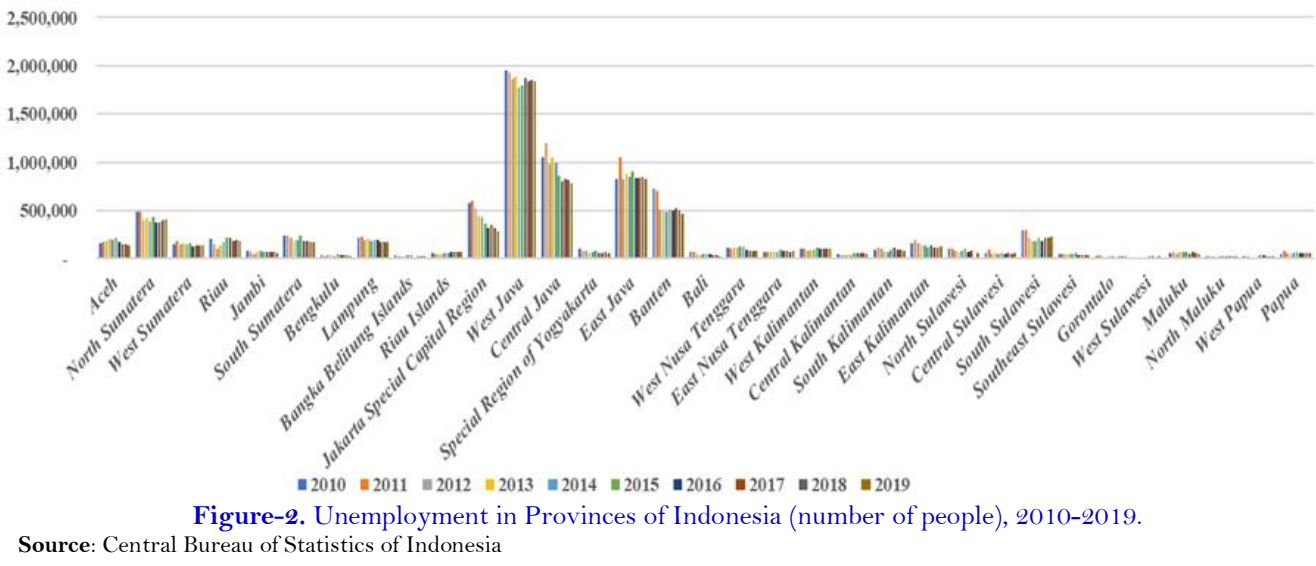

The number of poor people and unemployment over the period 2010-2019 in provinces of Indonesia seems to be declining. It is certainly the result of the goverment's work to reduce unemployment and poverty in every province of Indonesia. Therefore, it would be interesting to examine the areas that have had an impact in the decrease in unemployment in Indonesia.

Figure 3 shows three provinces with the highest monthly minimum wage. The first is Jakarta with 2,422,292 IDR, then Papua with 2,114,132 IDR and West Papua with 1,988,166 IDR. The lower monthly minimum wages in 
Indonesia are in East Java (957,905 IDR), Central Java (1,047,346 IDR) and West Java (1,097,921 IDR). The real minimum wage tends to rise as the Indonesian government's efforts increase the income of workers. It would be interesting to further analyze it has an impact in decreasing the number of poor people across Indonesia.

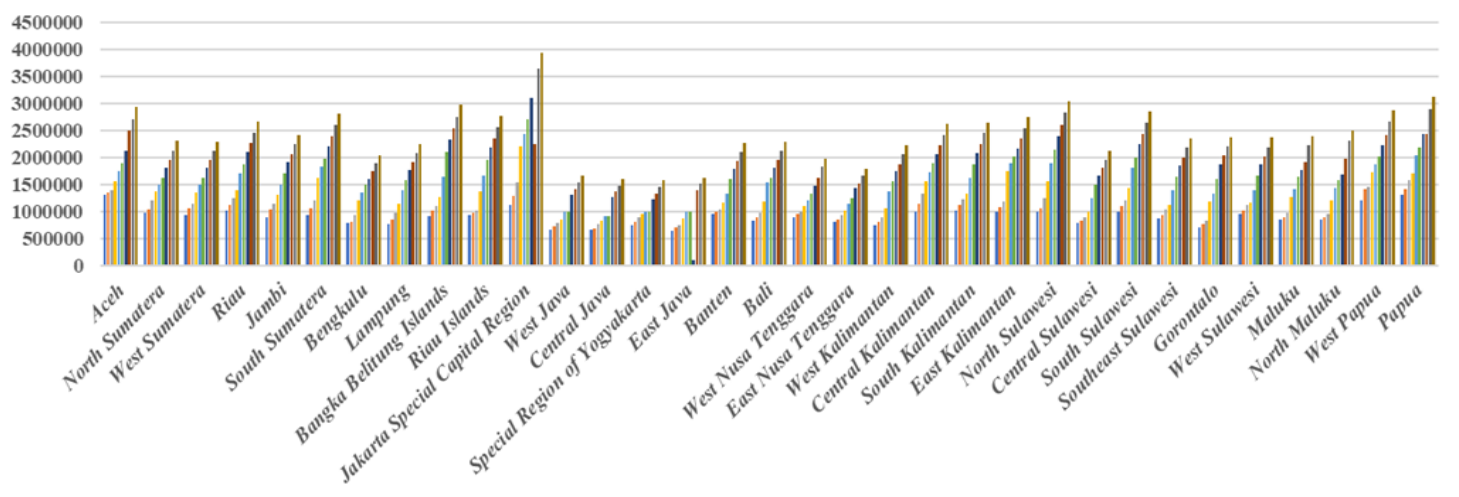

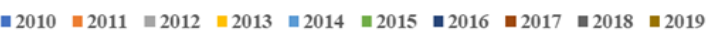

Figure-3. Minimum Wages in Province of Indonesia (IDR), 2010-2019.

Source: Central Bureau of Statistics of Indonesia.

A consistent value of GRDP reflects economic productivity in an area. The higher the value of GRDP, the more productive an area is. Every province in Indonesia over the period 2010-2019 shows an increase in GRDP. It means each province has succeeded in increasing its performance by increasing production during this period. Although the real GRDP of each province in Indonesia increased during this period, the efforts made by provincial goverments towards this increase need to be assessed regarding their impact on the reduction in the number of poor people in each province. Research by Zaman, Khilji, Awan, Ali, and Naseem (2014) in Pakistan explains that real GDP (economic growth) is the most efficient way to alleviate poverty, especially in the dominant economic sectors that play an important role in increasing their employees' income. The Pakistani government significantly decreased the number of poor people thorugh increased public income. The result of this research proves that economic growth (real GDP) in Pakistan has a negative significant effect on poverty.

Figure 4 indicates that there are three provinces in Indonesia over the period 2010-2019 that had the highest average real GRDP: Jakarta (1,432,054.75 billion IDR), East Java (1,305,797.38 billion IDR) and West Java (1,188,058.55 billion IDR). Meanwhile, the lowest average real GRDP was found in North Maluku (20,230.79 billion IDR), Gorontalo (2 1,609.99 billion IDR) and Maluku (24,422.37 billion IDR).

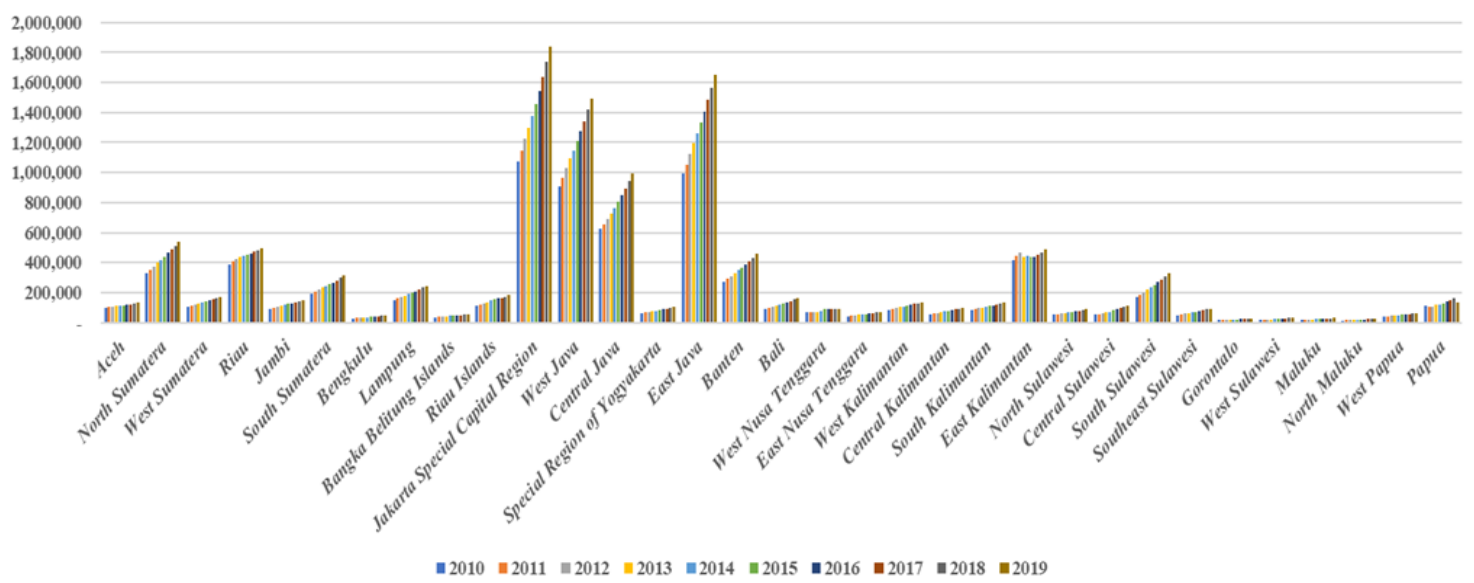

Figure 4. Real GRDP in Provinces of Indonesia (billion IDR), 2010-2019.

Source: Central Bureau of Statistics of Indonesia.

The novelty of this study is that the research focuses on different variables that are not mentioned in previous research. For example, research by Akinmulegun (2014) in Nigeria only discuss unemployment, while Zaman et al. 
(2014) discuss real GDP and its effect on poverty, and Shitile and Abubakar (2019) only examined the effects of foreign aid and grants on poverty in Nigeria. Additionally, this study uses a particular research methodology, namely panel data regression analysis with a fixed effect model approach, which was not used in earlier literature. Therefore, this study will focus on four variables (unemployment, wage, real GRDP and poverty) and use the methodology previously mentioned to respond to the research gap in the earlier study.

\section{LITERATURE REVIEW}

Akinmulegun (2014) explains that unemployment is a major cause of poverty in Nigeria. This research then suggests that the government carries out a structural transformation in macroeconomic policies on employment. The study by Adejimi and Ogunode (2015) also concluded that poverty in Nigeria was largerly influenced by the unemployment rate, although Nigeria was ranked 158th in the list of the most developed countries in the world. The unemployment rate is influenced by a lack of infrastructure facilities, a significant population increase and a school curriculum system with a limited number of educated teachers.

A study conducted by Berardi and Marzo (2015) proves the sector in Africa's GDP, such as the agriculture, has a lot of potential for the poor (pro-poor potential). African countries rely heavily on agricultural as the spearhead of their revenue. Therefore, through its policies, governments strive to encourage increased economic activity in the agricultural sector in order to increase labor demand. Through the use of a large workforce, public revenue is expected to increase and, in turn, improve the welfare of people in the country, and ultimately reduce the number of poor people across the continent.

Research regarding the effect of unemployment on poverty in European countries also has been studied Kiaušienè (2015). This study focused on unemployed women in 28 European countries using scientific literature analysis, comparison between countries, descriptive statistics and regression analysis. The study aimed to determine whether there is a correlation between unemployment and poverty in these countries. The result shows that unemployed women are positively correlated with the risk of experiencing poverty, meaning thatmore women out of employment increased poverty rate in that category. Conversely, it can be concluded that if the unemployment rate can be kept low then the number of poor people would decrease because people in employment generate revenue. Kiaušienë's study also found that fewer women than men were unemployed.

The same case is also examined by Kware (2015) in Nigeria. According to research, Nigeria is the strongest economic country in Africa. Kware conducted research on unemployment, inequality and poverty. Even though Nigeria has high economic growth, issues such as unemployment, inequality and poverty are still problems that are yet to be solved. The high rate of unemployment causes great disparity regarding personal income, which leads to severe inequality. This inequality between the different levels of income in urban communities and rural communities is evident, and consequently, poverty continues to rise.

Sabia and Nielsen (2015) examined the minimum wage situation in the United States. The study used data from the Survey of Income and Program Participation (SIPP) over the period 1996-2007. The results indicated an increase in minimum wage by the US government between 1996 and 2007, which had a positive impact on the poverty rate. It demonstrated that a minimum wage increase can reduce the poverty rate in the country. It is felt by all members of society in the US. Researchers emphasized that increasing the minimum wage is important, but also that the redistribution of income as a result of the increase is also important, especially for low-skilled workers.

Another study on minimum wage was carried out by Bolwell (2016). His study waas in relation to global minimum wage setting in order to reduce the poverty rate based on the international poverty line. The study explained how a global minimum wage could be introduced in all countries. According to the author, the basic introduction of a global minimum wage would entail the following: the calculation of the international poverty line by the World Bank, its application in developing countries, an invitation to broader stakeholders, and a rigorous 
monitoring process. The results show there is a positive effect if the minimum wage is applied globally because it helps to equalize wages between high-skilled and low-skilled jobs.

The next study, carried out by Kuada (2014) examined the effect of real GDP on poverty alleviation . This study was conducted in order to identify the relationship between economic growth and poverty using literature review methods that focused on economic development in Africa. Its purpose was to provide a complete description of the dominant issues of economic growth and poverty alleviation efforts. The results show that economic growth can positively influence social issues, especially for poor people, by reducing poverty. This demonstrates how economic growth should work, not limited to economic growth alone, but should also be inclusive of income distribution.

The other study on the effect of the increase in real GDP on poverty alleviation was conducted by Sasmal and Sasmal (2016) in India. This study aimed to identify a relationship between public expenditure, increasing real GDP (economic growth) and poverty alleviation. This study used panel data regression analysis with data from each state in India. The results of the study show that there is a significant positive relationship between public expenditure, economic growth and poverty alleviation. It can be seen from the states in India that high levels of public expenditure (for development, such as infrastructure, building construction, irrigation, electric power centers and communications), have proven to have an impact on high economic growth. Furthermore, the states that have high average economic growth have low poverty rates. It means there is a positive relationship between economic growth (the increasing real GDP measurement) and poverty levels.

Nyasha, Gwenhure, and Odhiambo (2017) stated in their study, that although analysis of economic growth and poverty alleviation can be met through a trickle down effect, there are still many alternative ways to examine it. The study gives an overview of economic growth and poverty using a dynamic causal linkage approach in Ethiopia over the period 1970-2014. Its method is the autoregressive distributed lag (ARDL), bounding test and ECM based on Granger Causality. The results of the study show that there is a short term negative causality between economic growth as measured by real GDP and poverty alleviation. Conversely, in the long term, causality is only found from economic growth to poverty alleviation, not vice versa. As a result, researchers recommended that the government prepare pro-poverty reduction policies through increasing economic growth (real GDP increase), which could be done in the short term.

Based on the literature review above, the hypotheses of this research relating to Indonesia are:
$H_{1} \quad$ : High unemployment has a significant negative effect on poverty.
$\mathrm{H}_{2}$ : Increasing the minimum wage has a significant positive effect on poverty.
$H_{s}$ : Real GRDP growth has a significant positive effect on poverty.

\section{RESEARCH METHODOLOGY}

This study used secondary data on 33 provinces in Indonesia over the period 2010-2019. The analysis technique used panel data regression analysis. This analysis combined cross section and times series data, which proved advantageous in providing solutions that cannot be reached by examining the two individually (Feriyanto, 2019). The research data in this analysis includes unemployment, wages, real GRDP and poverty. The data is taken from the Central Bureau of Statistics (Badan Pusat Statistik-BPS). The formulation of a specifications model in this study is Poverty $=f$ (unemployment, wage, real GRDP).

After examining the MWD (MacKinnon, White, and Davidson) test model, it was found that the best functional form for estimating poverty in provinces of Indonesia was in the form of a logarithmic (log) equation, as shown below:

$$
\log \mathrm{PVT}_{\mathrm{it}}=\beta_{0}+\beta_{1} \log \mathrm{UNEM}_{\mathrm{it}}+\beta_{2} \log \mathrm{W}_{\mathrm{it}}+\beta_{3} \log \text { real GRDP } \mathrm{Gt}_{\mathrm{it}}+\mathrm{e}_{\mathrm{it}}
$$

Description:

PVT = Poverty (people). 


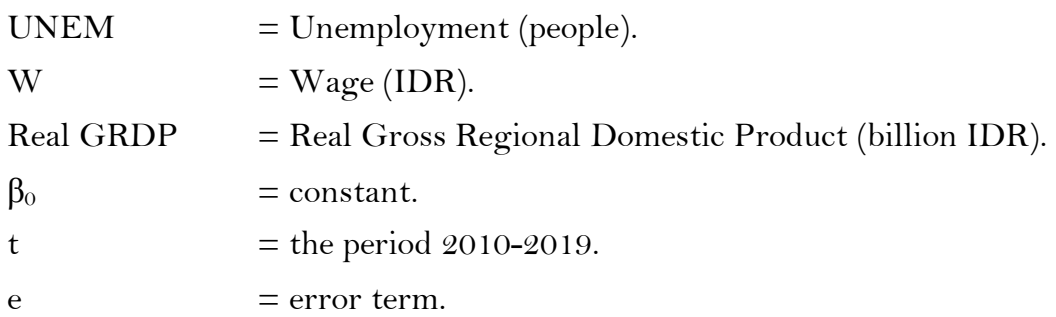

\section{ANALYSIS AND DISCUSSION}

Poverty models to be estimated used data from 2010-2019 (10 years), so the total pool of observation data includes up to $330(330=10$ years $\mathrm{x} 33$ provinces data). The test results of empirical data using theFixed Effect Model are as follows:

Based on Table 1, the value of $\mathrm{F}$ cross-section is 948.233090 and its probability value was 0.0000 . At $5 \%$ (0.05) of the alpha level, the probability value of $\mathrm{F}$ cross-section is less than the alpha level of $5 \%$, meaning that $\mathrm{H}_{0}$ is rejected. It means that the best panel data model used was the fixed effect model rather than the common effect model.

Table 1. Result of redundant fixed effects tests.

\begin{tabular}{|c|c|c|c|}
\hline $\begin{array}{l}\text { Redundant Fixed Effects Tests } \\
\text { Test cross-section fixed effects } \\
\text { Effects Test }\end{array}$ & Statistic & d.f. & Prob.* \\
\hline Cross-section F & 948.233090 & $(32,294)$ & 0.0000 \\
\hline Cross-section Chi-square & 1533.311643 & 32 & 0.0000 \\
\hline
\end{tabular}

Based on Table 2, the value of cross section random Chi-Sq. The statistic was 95.109116 and its probability value was 0.0000 . At $5 \%$ (0.05) of the alpha level, the probability value of a random cross-section was less than alpha $5 \%$, meaning $\mathrm{H}_{0}$ is rejected. This shows again that the best panel data model used was the fixed effect model, not the random effect model.

Table 2. Result of Hausman test: Fixed and Random effects.

\begin{tabular}{l|c|c|c}
\hline $\begin{array}{l}\text { Correlated Random Effects - Hausman } \\
\text { Test Test cross-section random effects }\end{array}$ & & \\
Test Summary & Chi-Sq. Statistic & Chi-Sq. d.f. & Prob.* \\
\hline Cross-section random & 95.109116 & 3 & 0.0000 \\
\hline
\end{tabular}

The results of an empirical assesment data using Fixed Effect Model are shown in Table 3 below:

Table 3. Regression result-dependent variable: Log PVT.

\begin{tabular}{l|c|c|c}
\hline Independent Variables & Coefficient & t-Statistic & Prob. \\
\hline Constant & 7.674437 & 18.14430 & 0.0000 \\
\hline Log UNEM & 0.044005 & 2.300698 & $\left.0.0221^{\mathrm{b}}\right)$ \\
\hline Log W & 0.014441 & 0.710433 & 0.4780 \\
\hline Log realGRDP & -0.193201 & -4.242774 & $\left.0.0000^{\mathrm{b}}\right)$ \\
\hline Note: ${ }^{\mathrm{a})}=$ significant at 0.10, and $^{\mathrm{b})}=$ significant at 0.05 level respectively.
\end{tabular}

R-squared $\quad 0.996990$

Adjusted R-squared 0.996632

F-statistic $\quad 2782.319^{\mathrm{b}}$

$\log \mathrm{PVT}_{\mathrm{it}}=\beta_{0} \quad+\beta_{1} \log \mathrm{UNEM}_{\mathrm{it}} \quad+\beta_{2} \log \mathrm{W}_{\mathrm{it}} \quad+\beta_{3} \log$ realGRDP $\mathrm{it}+\mathrm{e}_{\mathrm{it}}$

$\log \mathrm{PVT}_{\mathrm{it}}=7.674437+0.044005 \log \mathrm{UNEM}_{\mathrm{it}}+0.014441 \log \mathrm{W}_{\mathrm{it}}-0.193201 \log$ realGRDP $\mathrm{it}$ 
$\mathrm{R}^{2}=0.996990 \quad \mathrm{~N}=330 \quad \mathrm{~F}-\mathrm{stat}=2782.319$

\subsection{The coefficient of determination (Goodness Regression Testing)}

From the results of the regression that has been conducted, it was found that the value of $\mathrm{R}^{2}$ is 0.996990 or $99.70 \%$. This suggests that the fluctuation of the independent variables can explain the variation of the dependent variable by as much as $99.70 \%$ and the remaining is explained by variables outside the model.

\subsection{Test Statistic F (Feasibility Model)}

From the results of the regression,, the obtained value of the F-count is equal to 2782.319 and the value of the F-table obtained was 2.76 with a significance level of $\alpha=0.05$. If the result shows that $\mathrm{F}$ count is larger than $\mathrm{F}$ table then the conclusion is to reject $\mathrm{H}_{0}$. This means that all the independent variables jointly and significantly affect the dependent variable.

\section{RESULT AND DISCUSSION}

\subsection{Unemployment (UNEM)}

The result of the t-statistics UNEM showed a value of 2.300698 while the t-table is 1.316 (one-sided test) with $\alpha=5 \%$ and $\mathrm{df}=330-4=326$. The value of t-statistics UNEM is higher than t-table. It rejects $\mathrm{H}_{0}$. Moreover, the coefficient value of UNEM showed a value of 0.044005 it means UNEM had a positive impact on poverty and when unemployment rises by $1 \%$, poverty will increase by $0.044005 \%$. These results are in line with those of the study by Ayala, Cantó, and Rodríguez (2016); FitzRoy and Jin (2017) and Adelowokan, Maku, Babasanya, and Adesoye (2019).

Ayala et al. (2016) conducted a study of the factors that impact poverty in Spain. The analysis used the generalized method of moments (GMM) model, using panel data over the period 1987-2015. The results of the study proved that unemployment has a positive impact on poverty, while inflation has a negative impact. This finding supports the Spanish government's program in the form of unemployment protection which can reduce poverty in the country.

The study by FitzRoy and Jin (2017) explained the importance of unemployment policies in reducing poverty. The author found that the effective policies in place to eradicate poverty and inequality used two approaches. First, establish a basic incomethat will increase workers' revenue and ultimately reduce poverty. This policy needs to be followed by a second policy relating to the provision of jobs. Employment opportunities in the community will reduce unemployment, which, in turn, reduces poverty and income inequality.

Furthermore, Adelowokan et al. (2019) have also investigated the relationship between unemployment, economic growth and poverty. The study was conducted in Nigeria, using time series data over the period 19852015. The analytical methods use Augmented Dick Fuller, Johansen cointegration, Granger causality and ECM. The results show that the coefficient between unemployment and poverty was positive and significant at the first level. The implication of this study states that although a country still has high poverty rates, economic growth will continue to increase. Therefore, there must be a macroeconomic policy that can ensure equal distribution of income for all levels of society, including the poor who make up the majority of the unemployed.

\subsection{Wage $(W)$}

The results in Table 3 showed the probability of wage is 0.4780 or $47.80 \%$, with alpha $(\alpha)=10 \%$ (one-sided test). Because the probability is higher than alpha, so $\mathrm{H}_{0}$ is accepted. It means that wage had no significant effect on poverty in Indonesian provinces.

Minimum wages in Indonesia increase annually. The percentage increase is associated with economic growth and inflation. The minimum wage is paid by the company or industry to its workers. A person whose expenditure is 
below the poverty line is considered to be living in poverty. The poverty line is a line that shows the minimum expenditure for food and other essential items. Poverty in Indonesia is common in people who work in the informal sector whose jobs are relatively unskilled and labor-intensive, such as street vendors. Income from daily work is used for living expenses. If a person does not work, they will not receive a daily income and will still be included in the poor group. Therefore, even if wages rise, they will not reach the level of daily workers whose income depends on paid employment. In other words, wages do not significantly influence poverty reduction.

The results of this study are in line with the results of a study by Campolieti, Gunderson, and Lee (2012) on Canada. They found that the wage rate, usually measured by minimum wage, did not affect poverty rate. Minimum wage is only used as a political rhetoric, which is designed to eliminate poverty. Poor people usually work under the productivity target, so even if the minimum wage is set, due to low productivity their minimum wage will remain low and therefore remain poor. Also, research by Sosnaud (2016) concluded that the minimum wage had no relationship to poverty in Canada and in the US.

But the results of that study were not in accordance with the results of a study by Atkinson, Leventi, Nolan, Sutherland, and Tasseva (2017) and Quinn and Cahill (2017). They proved that increasing minimum wage has an impact in reducing the number of poor people.

Research by Atkinson et al. (2017) was conducted in the UK using the EUROMOD approach method, and tested whether tax-benefit reforms and increasing minimum wage can reduce poverty rate and reduce the gap in income inequality. The results proved that tax reform can have a positive effect on reducing inequality and poverty rates in the UK. Tax reforms include a more significant progressive tax structure, other alternatives for social fund transfers, including increasing minimum wage up to a suitable living wage, can reduce poverty in UK. The results also showed that increasing minimum wage can enable people to a better life.

The study by Quinn and Cahill (2017) in the US measured how effective minimum wage and tax credits are in the decline in poverty rates. The results of their study showed that the increase in tax credits and minimum wage has been proven to reduce poverty significantly. The government, therefore, should employ these two policies in order to ensure the fairer distribution of wealth. If there was a choice between tax credits or minimum wage, researchers recommend that governments would be better off using tax credit instruments than minimum wage, however, if both are used together then the increase in minimum wage and tax credits has a bigger impact in reducing poverty.

Furthermore, Sabia, Burkhauser, and Mackay (2018) have conducted research regarding minimum wage, restaurant tips and poverty. The study was conducted in the US using the March Current Population survey data over the period 1988-2014. The results indicated that minimum wage can have a significant effect in reducing poverty. The minimum wage in this case includes the policy of giving tips to restaurant employees. Therefore, researchers provide recommendations to provide a fair wage policy for workers, especially by increasing their minimum wage. By increasing the minimum wage, it is hoped that it will increase the workers' revenue and, in turn, reduce poverty.

The same study was also backed up by Churchill and Sabia (2019). They studied the minimum wage of immigrants with limited skills and its effect on poverty rates. The study is conducted in the US used data over the period 1994-2016. The results showed that the minimum wage setting for immigrants from Hispanic backgrounds helped to reduce poverty, meaning the higher the minimum wage, the lower the poverty rate. The researchers also found that increases in minimum wage were inconsistent. Policy recommendations, especially for countries that accept immigrants from abroad, including immigrants with limited skills, need to have a minimum wage setting policy, because it is proven to reduce poverty among low-skilled workers. 


\subsection{Real Gross Regional Domestic Product (real GRDP)}

The results calculated a probability value of the real GRDP of 0.0000 , which indicated that $\mathrm{H}_{0}$ is rejected. Moreover, the coefficient value of the real GRDP showed a value of -0.193201, meaning the real GRDP had a negative impact on poverty, and when the real GRDP rises $1 \%$, poverty will decrease by $0.193201 \%$.

This result is in line with the results of research conducted by Dauda and Makinde (2014); Sehrawat and Giri (2018) and Michálek and Výboštok (2019). The results of their study indicated that real GDP had a negative effect on poverty rates in the countries studied.

Dauda and Makinde (2014) carried out research on poverty alleviation in Nigeria. The study was conducted using data from 1980-2010. The study used an analysis of vector autoregressive models (VAR) with research variables including economic growth, financial deepening (M2), and poverty rates. The results showed that economic growth can reduce poverty in Nigeria. Meanwhile, the M2 variable in the study was found to be negatively and significantly related to poverty. Sehrawat and Giri (2018) examined research on economic growth, income inequality and poverty. It was conducted in India from 1970-2015 using the method of autoregressive distributed lag (ARDL) bounds testing. The results showed that there is a long-term correlation between financial development, economic growth, inequality and poverty. Moreover, economic growth (measured using real GDP) had a positive effect on the poverty rate,. Therefore, the recommendation is that a policy that needs to be developed based on the research to financial development and economic growth because it reduces inequality and poverty.

Meanwhile, Michálek and Výbošt'ok (2019) conducted research on economic growth, inequality and poverty in European countries using the growth incidences curve (GIC) method. The results of their study showed that economic growth (measured using GDP per capita) had a very strong impact on the reduction of poverty, but this effect was different in each of the countries studied. The findings stated that, during the crisis period, the countries with a strong economy were more capable of reducing poverty than countries with a weaker economy.

\subsection{Intercept Coefficient of Poverty in Provinces of Indonesia}

The Fixed Effect method showed that each province in Indonesia had a different intercept coefficient for poverty. A positive value of intercept coefficient explained that the development of poverty in provinces of Indonesia is higher than the average of poverty in provinces of Indonesia. Table 4 describes the provinces in Indonesia that have succeeded, and those that have been less successful in reducing poverty over the period 20102019.

Table 4. Intercept coefficient of Indonesian provinces.

\begin{tabular}{c|l|c|c|l|c}
\hline No. & Provinces & $\begin{array}{c}\text { Intercept } \\
\text { Coefficient }\end{array}$ & No. & Provinces & $\begin{array}{c}\text { Intercept } \\
\text { Coefficient }\end{array}$ \\
\hline 0 & All Provinces in Indonesia & 7.674437 & 17 & West Sumatera & 7.510586 \\
\hline 1 & East Java & 10.392241 & 18 & West Kalimantan & 7.479291 \\
\hline 2 & Central Java & 10.248481 & 19 & Southeast Sulawesi & 7.266262 \\
\hline 3 & West Java & 10.208485 & 20 & East Kalimantan & 7.232942 \\
\hline 4 & North Sumatera & 8.967318 & 21 & Jambi & 7.177578 \\
\hline 5 & Lampung & 8.692255 & 22 & Bengkulu & 7.125943 \\
\hline 6 & South Sumatera & 8.653305 & 23 & Maluku & 7.068565 \\
\hline 7 & East Nusa Tenggara & 8.39259 & 24 & West Papua & 6.871752 \\
\hline 8 & Papua & 8.386714 & 25 & South Kalimantan & 6.777861 \\
\hline 9 & South Sulawesi & 8.350595 & 26 & Bali & 6.746484 \\
\hline 10 & Aceh & 8.268068 & 27 & North Sulawesi & 6.733128 \\
\hline 11 & Banten & 8.194362 & 28 & Gorontalo & 6.562586 \\
\hline 12 & West Nusa Tenggara & 8.183685 & 29 & Central Kalimantan & 6.459727 \\
\hline 13 & Riau & 7.983294 & 30 & Riau Islands & 6.450022 \\
\hline 14 & Jakarta Special Capital Region & 7.866114 & 31 & West Sulawesi & 6.358764 \\
\hline 15 & Special Region of Yogyakarta & 7.746277 & 32 & North Maluku & 5.697745 \\
\hline 16 & Central Sulawesi & 7.527684 & 33 & Bangka Belitung Islands & 5.675716 \\
\hline
\end{tabular}


The provinces of East Java, Central Java and West Java are less successful in reducing poverty in Indonesia. This is indicated by a large value of intercept coefficient. Whereas West Sulawesi, North Maluku and Bangka Belitung Islands have succeeded in reducing poverty in their regions through reducing the number of programs aimed at getting people out of poverty. The government work scheme was developed in accordance with the Millennium Development Goals (MDG) program, which ended in 2015. Subsequently, the Sustainable Development Goals (SDG) program began in 2015 and will continue until 2030.

\section{CONCLUSION, IMPLICATIONS, AND RESEARCH LIMITATION}

The results showed that, in particular, unemployment has a significant negative effect on poverty, while the real GRDP had a significant positive effect on poverty in the provinces of Indonesia. Collaboratively, the variables of unemployment, wages, and the real GRDP also had a significant effect on poverty in the provinces of Indonesia.

Seeing the result of this study, unemployment had a negative impact on poverty in provinces of Indonesia. It indicated that the government needs to reduce unemployment. Implementing a policy on expanding employment opportunities, followed by higher labor absorption, will have an impact in reducing unemployment.

The results of this study also prove that the minimum wage has no impact on poverty in the Indonesian province. Wages will only affect workers in larger established companies or industries. Poor people in Indonesia mostly depend on income from daily work, not earning a wage. This means that if workers' wages are raised, it will not affect the income of the poor.

It is necessary for the government to provide wider employment opportunities for day-to-day workers so that they earn sufficient income to get off the poverty line. The government must continue to evaluate and improve the welfare of workers through increased wages for employees in companies or industries and therefore increasingpeople's discretionary income in order to improve the Indonesian economy. In setting an increased minimum wage policy, in addition to the government calculating the cost of living for workers, it must also consider a company's ability to pay workers' wages, as some companies may not be able to afford to increase wages. If labor productivity is still low and demand for higher wages continues to increase, it will certainly become an issue for employers.

Real GRDP is the dominant factor in reducing poverty in Indonesia. Therefore, it is necessary to increase the real GRDP urgently so that poverty in Indonesia can be significantly reduced. Increasing worker productivity is essential to increase the real GRDP in each province in Indonesia. If the real GRDP can be raised significantly it will create a better investment climate, which will open up wider employment opportunities, increase welfare and reduce poverty in Indonesia's provinces. Likewise, by increasing national income we create factors such as consumption, export and investment.

The limitation of this study is that the research was only conducted on 33 provinces in Indonesia over 10 years. The next study can be conducted on 34 provinces with a longer research time, so that a more complete study can be completed. In addition, the research can add other independent variables that affect poverty, such as inflation and climate change, so that it is more comprehensive.

Funding: Funding assistance is provided by Universitas Islam Indonesia to increase the productivity, and also supports the processing and publication fee of this scientific paper.

Competing Interests: The authors declare that they have no competing interests.

Acknowledgement: The authors would like to thank Universitas Islam Indonesia for providing financial and motivational support and assistance in the completion of this research.

\section{REFERENCES}

Adejimi, S., \& Ogunode, P. (2015). Implications of poverty and youth unemployment on Nigeria economy. Journal of Asia Entrepreneurship and Sustainability, 11(3), 1-27. 
Adelowokan, O. A., Maku, O. E., Babasanya, A. O., \& Adesoye, A. B. (2019). Unemployment, poverty and economic growth in Nigeria. Journal of Economics \& Management, 35, 5-17. Available at: https://doi.org/10.22367/jem.2019.35.01

Akinmulegun, S. (2014). Unemployment and poverty paradigm in Nigeria: Challenges and prospect. International Journal of Management and Administrative Sciences (IJMAS), 2(3), 16-23.

Atkinson, A. B., Leventi, C., Nolan, B., Sutherland, H., \& Tasseva, I. (2017). Reducing poverty and inequality through tax-benefit reform and the minimum wage: the UK as a case-study. The Journal of Economic Inequality, 15(4), 303-323. Available at: https://doi.org/10.1007/s10888-017-9365-7

Ayala, L., Cantó, O., \& Rodríguez, J. G. (2016). Poverty and the business cycle: A regional panel data analysis for Spain using alternative measures of unemployment. The Journal of Economic Inequality, 15(1), 47-73.

Berardi, N., \& Marzo, F. (2015). The elasticity of poverty with respect to sectoral growth in Africa. The Review of Income and Wealth, 63(1), 1-31. Available at: https://doi.org/10.1111/roiw.12203.

Bolwell, D. (2016). To the lighthouse towards a global minimum wage: Building on the international poverty line. Australian Bulletin of Labour, 42(1), 1-37.

Campolieti, M., Gunderson, M., \& Lee, B. (2012). The (non) impact of minimum wages on poverty: Regression and simulation evidence for canada. Journal of Labor Research, 33(3), 287-302. Available at: https://doi.org/10.1007/s12122-012-91398.

Churchill, B. F., \& Sabia, J. J. (2019). The effects of minimum wages on low skilled immigrants' Wages, employment, and poverty. Industrial Relations: A Journal of Economy and Society, 58(2), 275-314. Available at: https://doi.org/10.1111/irel.12232.

Dauda, R. O. S., \& Makinde, K. O. (2014). Financial sector development and poverty reduction in nigeria: A vector autoregressive analysis (1980-2010). Asian Economic and Financial Review, 4(8), 1040-1061.

Feriyanto, N. (2019). The effect of the quality of human development factors on the rate of economic growth in yogyakarta special province. International Journal for Quality Reserach, 13(1), 157-176. Available at: http://doi.org/10.24874/IJQR13.01-10.

FitzRoy, F., \& Jin, J. (2017). Basic income and a public job offer: Complementary policies to reduce poverty and unemployment. IZA Policy Paper No. 133, September. (1-28. Retrieved from: http://ftp.iza.org/pp133.pdf).

Kiaušienė, I. (2015). Comparative assessment of women unemployment and poverty in European Union. Intellectual Economy, 9(2), 91-101.

Konkel, R. (2014). The monetization of global poverty: The concept of poverty in World Bank history, 1944-90. Journal of Global History, 9(2), 276-300. Available at: https://doi.org/10.1017/S1740022814000072.

Kuada, J. (2014). Economic growth and poverty alleviation in Africa - Linking hard and soft economics. African Journal of Economic and Management Studie, 5(1), 2-8. Available at: https://doi.org/10.1 108/AJEMS-03-2014-0016.

Kware, A. A. (2015). Unemployment, income inequality and poverty: The hallmarks of the Africas Largest and strongest economy; Nigeria. Asian Economic and Financial Review, 5(1 1), 1239-1250.

Michálek, A., \& Výbošt’ok, J. (2019). Economic growth, inequality and poverty in the EU. Social Indicators Research, 141(2), 611 630. Available at: https://doi.org/10.1007/s1 1205-018-1858-7.

Nyasha, S., Gwenhure, Y., \& Odhiambo, N. M. (2017). Poverty and economic growth in Ethiopia: A multivariate causal linkage. The Journal of Developing Areas, 51(1), 343-359.

Quinn, J. F., \& Cahill, K. E. (2017). The relative effectiveness of the minimum wage and the earned income tax credit as antipoverty tools. Religions, 8(4), 1-17. Available at: https://doi.org/10.3390/rel8040069.

Sabia, J. J., \& Nielsen, R. B. (2015). Minimum wages, poverty, and material hardship: New evidence from the SIPP. Review of Economics of the Household, 13(1), 95-134. Available at: https://doi.org/10.1007/s11150-012-9171-8

Sabia, J. J., Burkhauser, R. V., \& Mackay, T. (2018). Minimum cash wages, tipped restaurant workers, and poverty. Industrial Relations: A Journal of Economy and Society, 57(4), 637-670. Available at: https://doi.org/10.1111/irel.12215. 
Sasmal, R., \& Sasmal, J. (2016). Public expenditure, economic growth and poverty alleviation. International Journal of Social Economics, 43(6), 604-618. Available at: https://doi.org/10.1108/IJSE-08-2014-0161.

Sehrawat, M., \& Giri, A. (2018). The impact of financial development, economic growth, income inequality on poverty: Evidence from India. Empirical Economics, 55(4), 1585-1602. Available at: https://doi.org/10.1007/s00181-017-1321-7

Shitile, T. S., \& Abubakar, S. (2019). Reassessing the efficacy of foreign aid and grants in poverty reduction in Nigeria. Asian Economic and Financial Review, 9(4), 450-960. Available at: http://www.aessweb.com/journals/April2019/5002/4547

Sosnaud, B. (2016). Living wage ordinances and wages, poverty, and unemployment in US cities. Social Service Review, 90(1), 334. Available at: https://doi.org/10.1086/686581.

Zaman, K., Khilji, B. A., Awan, U., Ali, G., \& Naseem, I. (2014). Measuring pro-poor sectoral analysis for Pakistan: Trickle down? Economic Research, 27(1), 713-728. Available at: https://doi.org/10.1080/1331677X.2014.975519 